\title{
ANALYSIS ON THE EFFECT OF CURRENT RATIO, CASHFLOW FROM OPERATION TO DEBT, FIRM SIZE AND RETURN ON EQUITY ON STOCK RETURN
}

\author{
Rochim $^{1 *}$, Nunung Ghoniyah ${ }^{2 *}$
}

* Affiliation:

${ }^{1,2}$ Magister Management Program, Islam Sultan Agung Islamic University

\begin{abstract}
:
This research is to learn some financial finance factor that can be used as a short prediction tool of return of investment decision in the form of stock. The object of research used in this study is a company incorporated in the Jakarta Stock Exchange during research periode 2012-2016. The variables studied were Profitability and Solvency. The analysis technique used in this research is linear regression. This research is done by quantitative method to the company's financial statements listed in Jakarta Stock Exchange during period 2012-2016. Total sample of research is 35 company, which determined by purposive sampling method. Hypothesis testing method was conducted using t-test different test and linear regression. The results of this study indicate that there is a positive influence between Current Ration (CR), Cash Flow from Operation to Debt (CFOD), Firm Size, Return on Equity (ROE) to stock returns listed in Indonesia Stock Exchange during 2012-2016.

Keywords: Current Ration (CR), Cash Flow from Operation to Debt (CFOD), Firm Size, Return on Equity (ROE)
\end{abstract}

\section{INTRODUCTION}

In the investment world, investors have the main goal to gain a profit (return). Returns received by company shareholders always fluctuate from year to year, so investors need information about the company from its financial statements. in making investment decisions, an investor needs to perform fundamental analysis obtained from the issuer's financial statements.

Fundamental analysis states that the level of company returns will affect stock price, the higher the rate of return, the higher the stock price. Fundamental information in general can be described as information relating to historical financial data of a company.

Fundamental analysis involves factors that provide information about company's performance, such as management capability in managing the company's operational activities, future business prospects and so forth. 
Hobarth (2006) in his research explained the correlation between financial indicators and performance of companies listed in the USA over a 19 years period, using 17 financial indicators and 3 variables to measure their performance such as market performance, cash flow performance, and profitability. The results of this study showed that companies with low market ratios are those that have efficient work capital management, low liquidity, large equity, and small liabilities, and retained high returns in corporate. Companies with high market ratios is a company with high liquidity, low equity, small amount of assets and returns. Furthermore, companies that have low market ratios, efficiency of working capital, large equity and small liabilities, low total assets, will have better market performance. Some researchers have conducted research on the influence of financial fundamental factors as a tool to measure company performance and Return Share as follows; Utami (2002) conducted research with the variables of Current Ratio, Return on Equity (ROE), Cashflow from operation to debt and Size firm resulting that the fundamental factors above have a significant influence on stock prices. Ratna Prihantini SE. (2009) conducted a study with the variables of Inflation, Current ratio (CR), Debt to Equity Ratio (DER) and Return of Assets (ROA) resulting that Current ratio has a significant effect on Stock Return. Miranda (2003) conducted a working study with the conventional concept of rate of return with the variables of cash flow and Stock Return resulting that net income in Cash Flow from Operating to Debt is not significant to improve stock return rate. Daniati and Suhaeri (2006) conducted research on the relationship between financial statement information and return from stock with the variables of Turnover Asset, Market Value, Size Firm and Cash Flow from Operation resulting that Size Firm significantly affects stock return. May Hotma (2009) conducted research on the influence of fundamental factors on stock return with the variables of Current ratio (CR), Cash Flow from Operation to Debt, Return on Equity (ROE) and Firm Size resulting that Return on Equity ROE) has significant effect on Stock Return.

From the results of the above studies, there are also research that resulted in different result analysis such as Subalno (2009) and Hermendiastoro (2005) who conducted research on the effect of Current Ratio (CR) on stock return with the result of analysis that Current Ratio (CR) has a negative effect on stock returns. Nathaniel (2008) and Prihantini (2009) conducted research on the effect of the variables of liquidity (cash flow from operation) and firm asset (Firm Size) resulting that those two variables have not significant effect on stock return. Susilowati and Turyanto (2011) conducted research with the variables of Return on Equity (ROE ) resulting that Return on Equity (ROE) has negative effect on Stock Return. In this study, it also analyzed how companies can increase stock return by using fundamental factors in running the company's operations such as by increasing Current Ratio (CR), Cashflow and Firm Size which have an effect on the increase of Return on Equity (ROE) as well as stock return. Based on the results of research that has been done, there are still many that produce different results from each other. Some of them use variables such as Current Ratio, Return on Equity, Cash Flow from Operation to Debt (CFOD) and Firm Size as independent variables. 


\section{LITERATURE REVIEW \\ Fundamental Analysis}

The concept of stock analysis can basically be divided into two, namely technical and fundamental analysis. Technical analysis is a form of analysis that is based on the publication of market data that includes stock prices, trading volume, stock index, and other technical indicators. The analysis is also called Market Analysis (Husnan, 1993). While Fundamental analysis can be divided into two, namely fundamental analysis that is external and fundamental analysis that is internal. If company has good prospect, then the stock price will reflect that information in the form of an increase in stock prices, and vice versa. While fundamental analysis of an external nature is a study that examines various matters related to information coming from outside of a company i.e. macro such as inflation, exchange rate, and GDP.

Internal fundamental analysis basically performs a historical analysis of company's financial strength so-called company analysis. With fundamental analysis, investors can estimate the rate of return on their investment. In fundamental analysis, a company that sells shares needs to be the center of attention of investors. The considerations include (1) Company's financial position, (2) Profit margin of corporate return growth, (3) Company Liquidity, (4) Leverage level to shareholder's equity, (5) the composition and the growth of company's operations

\section{Stock Return}

According to Elton and Gruber in Faried (2008), Stock Return is showing ownership rights on the returns and assets of a company. Simply, Stock can be defined as follows:

a. Stocks are Securities as evidence of inclusion or ownership of individuals as well as business entities / institutions within a company.

b. Returns refer to the return of results or profit on a securities or capital investment, the amount of which is expressed in an annual percentage rate.

So Return is the result obtained from an investor on the ownership of stocks of a company as an investment. Any investment in the form of stocks is influenced by the value of a company which is one of the factors that helps determine changes in the price of shares traded in Exchange. Jogiyanto, H.M. (1998) divided the concept of return into two groups: single return and portfolio return. Single return is the result obtained from the investment in the form of return realization and return expectations. Where the realized return is a return that occurs calculated based on historical data and serves as one of the company's performance measurement. Historical returns are also useful as a basis for determining expected returns in the future. Return expectations are expected returns that will be obtained by investors in the future (Jogiyanto, 1998). Return realization is calculated by the following formula:

$$
R t i=\frac{(P t i-P t i-l}{P t i-l}
$$

Where:

Rti = Stock Return

Pti = Stock 'I' Price at the end of period

Pti-1 = Stock 'I' Price at the beginning of period 


\section{a. Current Ratio}

Current Ratio is the ratio used to measure a company's ability to pay its short-term liabilities by using current assets. The low ratio means the company is unable to pay its liabilities as soon as possible, and is unable to take advantage of the cash cut or other expected matters. Whereas a high ratio means that the used money in running a company is held in a government's securities, savings, cash or other funds (Gill \& Chatton, 2003, p.40).

Current Assets

Current Rat=

\section{Current Liabilities}

Current Ratio is an indication of a company to meet market liquidity and ability to meet the demands of the creditor (Sawir, 2005). The acceptable current ratio varies from industry to industry. If the current ratio of the company is within this range, then it is generally considered to have good short-term financial strength. If current liabilities exceed current assets where the current ratio is below 1, then the company may have problems in fulfilling its short-term liabilities. Current Ratio is too high, then the company can not efficiently use current assets or short-term financing facility.

It can also point to problems in working capital management. A low ratio value (value less than 1) indicates that the company is experiencing financial difficulties in meeting its current obligations especially Short-term Liabilities.

Some researchers have conducted research on the influence of Current Ratio on stock return with the following results: Utami (2002) conducted a study on the influence of financial fundamental factors of Current Ratio (CR) which is significant to stock returm. Prihantini (2009, Ulupui (2005) and Astuti ( 2006) conducted research on the effect of Stock Return with the result that Current ratio has a significant positive effect on stock return. Furthermore, Subalno (2009) and Hermendiarso (2005) showed that Current Ratio has a significant positive effect on Stock Return.

Based on the explanation above, the hypothesis can be formulated as follow:

H1 : Current Ration has significant effect on Stock Return

\section{b. Cashflow From Operation to Debt (CFOD)}

Company's performance parameters that get the attention of investors and creditors are Cash Flow Statements. The cash flow statements report cash receipts and disbursements for a period derived from operating, investing and financing activities. Bowen et.al (1986) stated that the benefits of cash flow statements are to predict failure, assess risk, leverage forecasting, corporate valuation, and provide additional information on the capital market. Lee Et. Al. (2001: 242) stated that the information presented Cash Flow is more useful in assessing or analyzing decisions, both about stock investment and other cash forecasting purposes. The existence of information on Cash Flow is viewed by information users as complementary to evaluate company performance. Cash flow information has an information content if at the time of the announcement there is a market reaction. The market reaction shows that there is a change in the price of the security that is measured by the return of the value per price material or using 
the abnormal return. Research on the effect of cash flow and earnings on stock return has been done by many researchers such as Handoyo (2006) who conducted research on how the influence of cash flow on stock return. His research proved that changes in total cash flow has an effect on stock returns. Martanti et al (2009) tested the relationship between stock return and cash flow information showing the relationship of positive influence. In line with the research conducted, it showed that the cash flow affects the rate of return of stock returns. Triyono and Hartono (2010) examined the influence of earnings and cash flow information on price and stock returns. His research proved that information on net income, operating cash flow, investment cash flows, cash flow of financing activities and total cash flow does not affect price and stock returns. Based on the above description, then the research hypothesis is formulated: H2 : Cashflow of a company has significant effect on stock return

\section{c. Firm Size}

Firm size describes the size of a company indicated by total assets, total sales, average total sales and average total assets. Thus, the size of the company is the size or amount of assets owned by the company. (Sujianto, 2001).

Firms with larger sizes have greater access to sources of funding from multiple sources, so getting loans from creditors will be easier because large firms have a greater probability of winning the competition or staying in the industry. On the other hand, small-scale firms are more flexible in the face of uncertainty, as smaller firms react quickly to sudden changes. Therefore, enabling large companies leverage level will be greater than small companies.

Company size is measured from the total assets owned by the sample company. Total assets are resources owned by the company that will provide economic benefits in the future. This study used total assets as company size. Some companies look at firm size of total assets held, while other companies use revenue and market size (Bernard, 2003).

The study added firm size as an independent variable because investors invest their capital by considering the size of the company. The size of the company will affect the ability to bear the risks that may arise due to various situations faced by companies related to its operations (Ismail, 2004: 52). Firm Size is usually measured using total assets, sales and capital owned by a company.

As stated by Lauterbach and Vaninsky (1999) in Soleman (2008: 414), that a large size firm typically has greater net income than the small one. It has greater net income.

Some researchers have conducted research on the effect of Corporate Size on stock returns with the following results: Astuti (2006) and Widodo (2007) conducted research resulting Firm Size has a positive significant influence on stock return. Indriani (2005) found that companies that have total assets in large numbers, have reached the maturity stage because at that stage cash flow has been positive and is considered to have better prospect in long term. In addition, firms with large total assets are relatively more stable and more capable of generating returns compared to the smaller companies. Based on the above description, then the research hypothesis is formulated:

H3 : Firm size has significant effect on stock return 


\section{d. Return on Equity}

This ratio is the ratio used to measure the ability of the capital itself to generate profits for all shareholders, both common stock and preferred stock. Keown, et al. (2005, p.79) disclosed that "Return on equity indicates the accounting rate of return on stockholder's investment, as measured by net income relative to common equity". The low ratio means the performance of the company is not efficient in generating return on existing equity. Whereas the high ratio means the company's performance is efficient in generating return on existing equity.

Net Income

\section{Return on Equity = \\ Stockholder's Equity}

Other studies that are related to the profitability of the company ROE (Return on Equity) which is also related to examine the effect of Current Ratio (CR), Cashflow from operation to debt (CFOD) and Size (Size) Company directly or indirectly on Retrun on Equity (ROE) are as follows:

\section{a. Current Ratio ( CR )}

Current ratio (CR) is calculated by comparing current assets with current liabilities to be paid by the company. If the CR level is high, then the company is said to be able to pay all its short-term liabilities to the creditor. However, high CR is also not good because it will show that there is an excess of current assets that are not used effectively so that it can lead to reduced profits or profitability level, which can also result in a decrease in ROE (Sartono, 2013: 122). Based on the above description, then the research hypothesis can be formulated:

H4 : Current Ration ( CR ) has significant indirect effect on Return on Equity ( ROE )

\section{b. Cash flow from Operation To Debt ( CFOD)}

Cash Flow from Operation to Debt (CFOD) according to the researchers (Arieska and Gunawan, 2011), Minton and Schrand (1999) negatively affects investment and profitability of the company. This is because cash flow in the company is mostly used to finance research and development, as well as advertising costs, while for investment has a small portion. Vogt and $\mathrm{Vu}$ (2010) examined the impact of large level of cash flow operation on long-term performance of a company. Companies with the highest cash flow rate will have higher returns than those with low cash flow rates where if it is at low profitability and Return on Equity (ROE) it is also low. Based on the above description, then the research hypothesis can be formulated:

H5 : Cash flow from operation to Debt ( CFOD) has significant indirect effect on Return on Equity (ROE)

\section{c. Firm Size}

Firm Size is a factor that can determine the profitability of a company. The size of the company is considered capable of affecting the profitability of the company. Because the larger the size or scale of the company, the easier the company obtain sources of funding both internal and external. Firm size is stated positively and significantly related to firm value (Rachmawati and Hanung, 2007). However, it has negative and insignificant value by Siallagan and Mas'ud (2006). Based on the results of the research description above, then the research hypothesis can be formulated:

H6 : Firm Size has no indirect effect on Return on Equity (ROE) 


\subsection{Conceptual Framework}

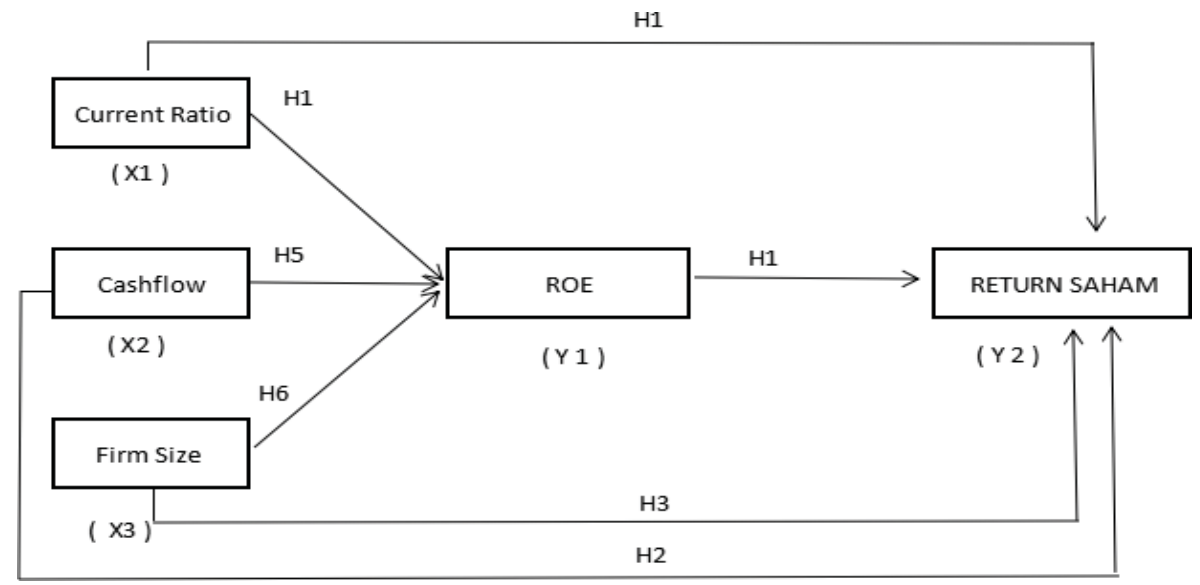

Figure 1. Conceptual Framework

Fun (1999) in Jefrie's research (2010) found the balance sheet and profit and loss ratios have a stronger relationship with stock return compared to cash flow. Keneddy (2001) examined the effect of ROA, ROI, Earning per share, Profit Margin, Asset Turnover, Leverage Ratio, and Debt to Ratio to stock return. Although, individually the relationship remains low, but together they have a real effect on the dependent variable of manufacturing company. Based on the background, problem formulation, and theoretical review, then the relationship between variables in this study can be expressed in the model as follows.

\section{RESEARCH METHOD}

The research design used in this research will be analyzed using descriptive statistics. This analysis aims to illustrate how much effect of the company's fundamental factors on the value of stock returns on manufacturing companies listed on the Indonesia Stock Exchange. The sample in this study was determined through purposive sampling which has the purpose of looking for the influence of the fundamental factors of the company to the return of go public company. This can be seen from the company's financial statements. The sample of this study was manufacturing companies listed on the Indonesia Stock Exchange (BEI) with the following criteria: (1) Companies that are listed on the Indonesia Stock Exchange in 2012 or earlier. (2). Companies that issue Financial Statements as of December 312012 to 2016 (3). Companies that present annual financial statements, (4). Companies that have a positive after-tax net profit. (5) The data required for research variables for each company are presented and completely available. The data used in this study were secondary data obtained from the internet (www.idx.com) including: (a) Financial statements of companies that go public on the Indonesia Stock Exchange 2012 until 2016. (b) Share Price is stock prices of companies that go public on the Indonesia Stock Exchange during the period 2012 to 2016 (c) Other supporting data. The data collected were analyzed using Multiple Regression with the assistance of SPSS program version 11.5. The purpose of this method is to predict changes in dependent variables associated with changes occurring in a number of independent variables. 


\section{FINDINGS \& DISCUSSION}

The hypotheses testings were done by looking at the significance value of each relationship. The level of Significance $(\alpha)$ was set at 5\%, which means that the tolerable error limit is $5 \%$. In other words, the level of confidence of this hypothesis testing is $95 \%$. If p-value $<0.05$, then it can be said that the independent variable has a significant influence on the dependent variable. This study proposed 5 hypotheses and the following can be seen the results of the hypotheses testing one by one, as follows:

Table 1. The Result of Regression Testing on the First Equation

Coenticients ${ }^{*}$

\begin{tabular}{|c|c|c|c|c|c|c|}
\hline \multirow[b]{2}{*}{ Made } & & \multicolumn{2}{|c|}{ Unstandardized Coefficients } & \multirow{2}{*}{$\begin{array}{c}\begin{array}{c}\text { Standardized } \\
\text { Coefficients }\end{array} \\
\text { Beta }\end{array}$} & \multirow[b]{2}{*}{$t$} & \multirow[b]{2}{*}{ Siq. } \\
\hline & & $\underline{B}$ & Std. Error & & & \\
\hline \multirow[t]{4}{*}{1} & (Constant) & 76.592 & 38.900 & & 1.969 & .053 \\
\hline & Current Ratio & -12.069 & 5.924 & -.245 & -2.037 & .045 \\
\hline & Cashflow & .043 & .112 & .046 & .387 & .700 \\
\hline & Firm Size & .256 & 1.883 & .016 & .136 & .892 \\
\hline
\end{tabular}

a. Dependent Variable: ROE

Source: Data calculated using SPSS 16.0

The form of multiple linear regression equation is as follow:

Return on Equity $($ Y1 $)=-0,245$ Current Ratio +0.046 CFOD +0.016 Size $+€$

From

It can be known from the second regression equation above that:

1. Curent Ratio regression coefficient equals to -0.245 meaning that if the Curent Ratio is increased by $1 \%$, then the Return on Equity will decrease by $0.245 \%$

2. CFOD regression coefficient equals to 0.046 meaning that if the CFOD is up by $1 \%$, then the Return on Equity will rise by $0.046 \%$

3. The regression coefficient of Company Size is 0.016 meaning if the size of this company rises by $1 \%$, then the stock return will rise by $0,016 \%$. 
Table 2. The Result of Regression Testing on the Second Equation

Coefficients

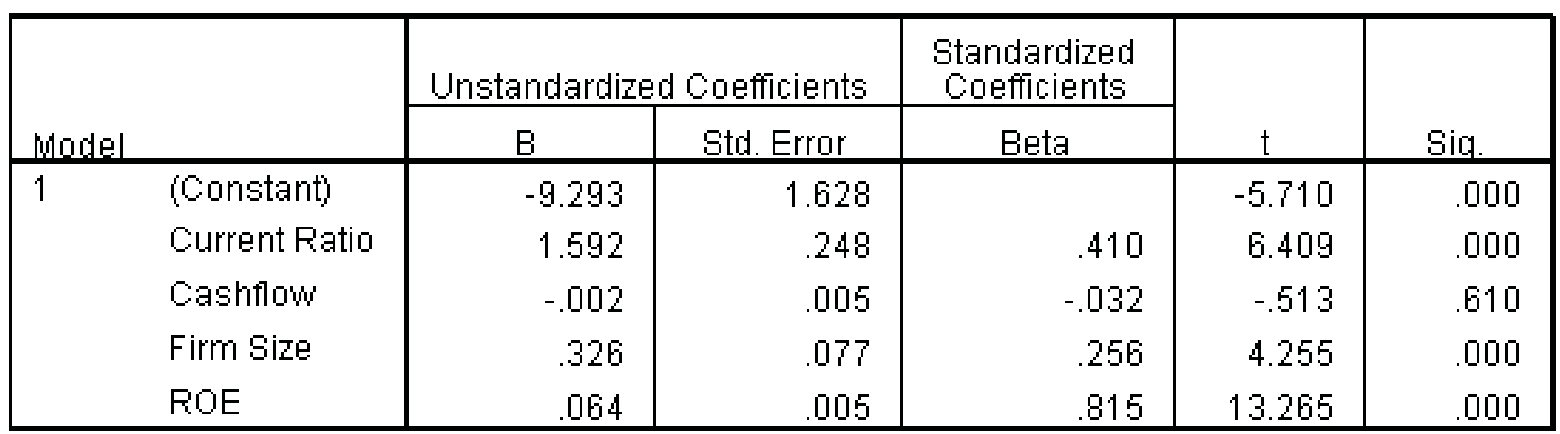

a. Dependent Variable: Return Saham

Source: Data calculated using SPSS 16.0

The form of multiple linear regression equation is as follow:

Stock Return $($ Y2 $)=+410$ Current Ratio -0.032 CFOD +0.256 Size $+0.815 \mathrm{ROE}+€$

It can be known from the multiple regression equation that:

1) Regression coefficient of Curent Ratio (CR) equals to 0,410, meaning that if Curent Ratio increases $1 \%$, then stock return will rise $0,410 \%$

2) The regression coefficient of Cashflow from Operation to Debt (CFOD) is - 0.032 , meaning that if cashflow from operation to debt is increased by $1 \%$, then the stock return will be decreased by $0,032 \%$.

3) The regression coefficient of Company Size is 0.256 meaning that if the size of this company rises $1 \%$, then the stock return will rise by $0.256 \%$.

4) Regression coefficient of Return on Equity (ROE) equals to 0815 meaning that if the ROE of this company rises by $1 \%$, then the stock return will rise by $0.815 \%$

\section{HYPOTHESES TESTING}

To test the hypothesis, it was tested partially to see the significance of the influence of each independent variable on the dependent variable by assuming other variables are constant.

Table 3. The Conclusion of T Test Result on the First Equation

\begin{tabular}{|l|l|l|l|}
\hline Variable & Coefficient & Sig. & Conclusion \\
\hline CURRENT RATIO & $-0,245$ & 0,045 & $\mathrm{H}_{01}$ accepted \\
\hline CFOD & 0,046 & 0,700 & $\mathrm{H}_{02}$ rejected \\
\hline SIZE & 0,016 & 0,892 & $\mathrm{H}_{03}$ rejected \\
\hline
\end{tabular}

a. Current Ratio (CR) has an effect on ROE

Based on Table 4.8 above, it can be seen that the Current Ratio has a negative effect -0.245 with a significance value of 0.045 which is lower than 0.05 so the hypothesis based on the empirical data is approved. 
b. Cashflow from Operation to Debt ( CFOD ) has an effect on ROE

Based on Table 4.8 above, it can be seen that Cash flow from Operation to Debt (CFOD) has a positive effect of 0.046 and has the significance value of 0.700 which is greater than 0.05 so the hypothesis based on empirical data above is rejected.

c. Size has an effect on ROE

Based on Table 4.8 above, it can be seen that Size has a Positive effect of 0.016 on Return on Equity with significant value of 0.892 which is greater than 0.05 . So the hypothesis based on empirical data above is rejected.

Table 4. The Conclusion of T Test Result Testing on the Second Equation

\begin{tabular}{|l|l|l|l|}
\hline Variable & Coefficient & Sig. & Conclusion \\
\hline CURRENT RATIO & 0,410 & 0,000 & $\mathrm{H}_{01}$ accepted \\
\hline CFOD & $-0,032$ & 0,610 & $\mathrm{H}_{02}$ rejected \\
\hline SIZE & 0,256 & 0,000 & $\mathrm{H}_{03}$ accepted \\
\hline ROE & 0,815 & 0,000 & $\mathrm{H}_{07}$ accepted \\
\hline
\end{tabular}

d. Current Ratio has an effect on Stock Return

Based on the table 4.9 above, it can be seen that the Current Ratio has a positive effect of 0.410 on stock return. The significance value is 0.000 or less than 0.05 so the hypothesis based on empirical data above is approved.

e. Cashfow from Operating to Debt (CFOD) has an effect on Stock Return

Based on Table 4.9 above, it can be seen that Cash flow from Operation to Debt has a positive effect of -0.032 on stock return. The significance value resulted 0.610 which is greater than 0.05 . The hypothesis based on empirical data above is rejected.

f. Firm Size has an effect on Stock Return

Based on Table 4.9 above, it can be seen that Firm Size has a positive effect of 0.256 on stock return. It also resulted significance value of 0.000 which is smaller than 0.05 , Then, the hypothesis based on empirical data above is received.

g. Return on Equity (ROE) has an effect on Stock Return

Based on Table 4.9 above, it can be seen that Firm Size has a positive effect of 0.256 on stock return. It also resulted a significance value of 0.000 which is smaller than 0.05 , then the hypothesis based on empirical data is accepted.

\section{CONCLUSION}

Based on the results of data analysis and discussion of research findings that have been done, the conclusions in particular and brief can be described as follows: to be able to increase stock return, company can perform the steps by increasing Curret Ratio company. If the current ratio increases, it means that the company is efficient in running its operational so that it can increase its profitability, mainly resulting profit productivity generated by its own capital source or Return on Equity (ROE). 
Ratio increase of Return on Equity (ROE) of a company becomes an indicator that the company is managed with good performance level where the impact would be responded by investors / markets that the stock in circulation will get increased return. While other fundamental factors of cash flow and assets have no influence response on a strong market, because although cash flow and assets are increased, they have no impact on Stock Return. Thus, if ROE increases then the net profit obtained from a company's operations with its own capital where its ROE is higher, the company will likely get a large income as well as Stock Return.

\section{REFERENCE}

Asyik,Nur Fadjrih.(1999)."Tambahan Kandungan Informasi Arus Kas".Jurnal Riset Akuntansi Indonesia.Vol.02.No.02,1999.

Dwi Martini, Mulyono, and Rahfiani Khairurizka. (2009), “The Effect Of Funancial Ratios, Firm Size, And Cash Flow From Operating Activities In The Interim Report To The Stock Return”. Chinese Business Review, Vol. 8 No. 6, 2009, pp.44-52.

Ghozali, Imam. (2009), “Aplikasi Analisis Multivariate Dengan Program SPSS”. Semarang: Badan Penerbit Universitas Diponegoro.

Gill, O James, And Chatton. (2003). "Memanfaatkan Informasi Keuangan Untuk Mengendalikan Bisnis Anda”. Memahami Laporan Keuangan. Jakarta : Lembaga ManajemenPPM.

Gujarati, Damodar (1999).’Ekonomitrika Dasar", Terjemahan Sumarno Zair, Jakarta : Erlangga.

Hotma, Mei (2009). "Pengaruh Faktor Fundamental Terhadap Return Saham Pada Perusahaan Manufaktur Yang Terdaftar Di Bursa Efek Indonesia”. Universitas Sumatera Utara. Tesis

Indonesia Stock Exchange (2010). “Indonesian Capital Market Directory”. Jakarta: PT Bursa Efek Indonesia.

Livnat, Joshua and Zorrowin Paul. (1990). "The Incremental Content Of Cash Flow". Journal of Accounting and Economic.Vol.14,1990, pp.25-46.

Keown, Arthur J et.al. (2005). Financial Management (10 ${ }^{\text {th }}$ edition).New Jersey,USA: Pearson Prentice Hall.

Nur,Deswin.(1999).’Rasio-Rasio Keuangan Dan Keterkaitannya Dengan Return Saham”. Universitas Indonesia.Tesis.

Prasetyo,Hendra. (2007).”Analisis Kinerja Keuangan Pada PT. Kalbe Farma,Tbk dan PT. Tempo Scan Pacific, Tbk Dengan Menggunakan Metode Analisis Rasio dan Dupont Analisis Selama Periode 2004-2006”.Universitas Tarumanegara.Tesis.

Triyono dan Yogiyanto.(2000). "Hubungan Kandungan Informasi Arus Kas, Komponen Arus Kas dan Laba Akuntansi Dengan Harga atau Return Saham”. Jurnal Riset Akuntansi Indonesia.Vol.3 No.1,2000, pp.54-68. 